\title{
Growth-dependent mortality of larval plaice Pleuronectes platessa in the North Sea
}

\author{
Frans Hovenkamp
}

Netherlands Institute for Sea Research, PO Box 59, 1790 AB Den Burg (Texel), The Netherlands

\begin{abstract}
Otoliths of larval plaice were studied over 3 yr in samples from offshore locations and from larvae immigrating into a nursery ground. Growth-dependent mortality was demonstrated to have operated in all years by comparing back-calculated otolith growth from both sample sites and survival ratios for larvae with different otolith growth rates. A distinction was made between mortality due to differences in growth, i.e. a longer larval-stage duration (growth-dependent), and mortality due to heavier predation on smaller or more vulnerable larvae (size-selective). It is argued that no size-selective mortality need have occurred, and that the observed differences in survival may have originated exclusively from differences in growth rate.
\end{abstract}

As in most marine fishes the larval phase of plaice Pleuronectes platessa L. is characterized by a rapid increase in weight and a high mortality rate. Year-class strength is to a large extent determined during the egg and larval stages (Veer 1986). Predation, starvation and drift are the most important factors likely to contribute to mortality, complicated by the fact that they may all act simultaneously and interact with each other.

Small size or starvation may cause a reduction in larval swimming speed and escape ability (Bailey 1984 Bailey \& Batty 1984) and, while not directly lethal, may contribute to mortality by enhancing predation. Reduced growth rates will also contribute to mortality by lengthening the period during which larvae are vulnerable to predation (Houde 1986, 1989).

Such a growth-dependent mortality can be demonstrated by comparing growth histories of the surviving part of a cohort with growth during the earlier stages. Existence of daily growth increments in the otoliths of fish larvae (Pannella 1971, Campana \& Neilson 1985), where width is related to somatic growth (Wilson \& Larkin 1982, Volk et al. 1984, Hovenkamp 1990), presents the possibility of investigating growth-dependent mortality during larval stages, by comparing past and present growth histories. The aim of this paper is to evaluate the influence of growth rate on mortality during the larval stages of plaice in the Southern Bight of the North Sea in the years 1987, 1988 and 1989. Plaice larvae were sampled during the larval phase in the open sea and during immigration into the nursery grounds of the Dutch Wadden Sea, and their early otolith growth is compared with that of the immigrating larvae.

Material and methods. At sea, larvae were sampled during a number of cruises with the RV 'Aurelia' (Fig. 1. Table 1). Double oblique hauls were made using an Isaacs-Kidd mid-water trawl (length $17 \mathrm{~m}$, opening $7.3 \mathrm{~m}^{2}$, mesh size $1.4 \mathrm{~mm}$, towing speed ca $2.5 \mathrm{knots}$ ).

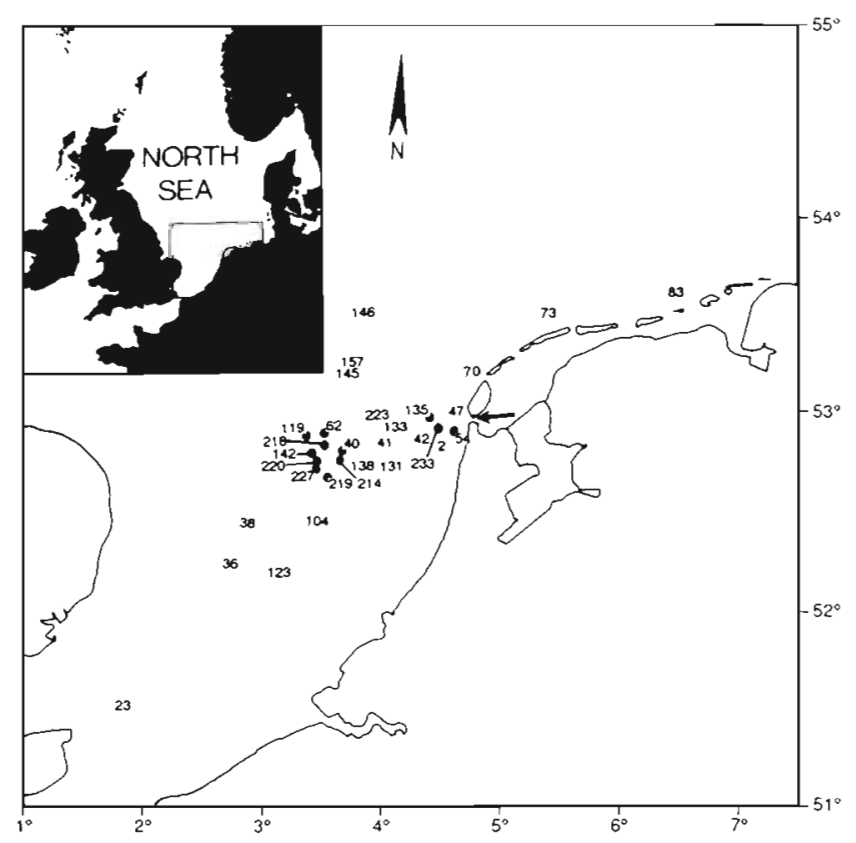

Fig. 1. North Sea showing sampling stations. Stns 1 to 100 were sampled in 1987, Stns 101 to 200 in 1988 and Stns 201 to 300 in 1989. Arrow: location of inshore sampling 
Table 1. Larval plaice collections 1987 to 1989. Station, date and cruise, location and temperature. Hauls taken at approximately the same time and location are shown as 1 station

\begin{tabular}{|c|c|c|c|c|c|}
\hline Station & Date & Cruise & Latitude & Longitude & $\begin{array}{l}\text { Temp. } \\
{ }^{\circ} \mathrm{C}\end{array}$ \\
\hline 2 & $23 \mathrm{Feb}$ & $1987-1$ & $52^{\circ} 47^{\prime} 34$ & $4^{\circ} 29^{\prime} 33$ & 4.8 \\
\hline 23 & $25 \mathrm{Feb}$ & 1987-1 & $51^{\circ} 27^{\prime} 84$ & $1^{\circ} 52^{\prime} 48$ & 5.1 \\
\hline 36 & $26 \mathrm{Feb}$ & $1987-1$ & $52^{\circ} 10^{\prime} 49$ & $2^{\circ} 45^{\prime} 46$ & 5.0 \\
\hline 38 & $26 \mathrm{Feb}$ & $1987-1$ & $52^{\circ} 22^{\prime} 78$ & $2^{\circ} 56^{\prime} 35$ & 4.9 \\
\hline 40 & $26 \mathrm{Feb}$ & $1987-1$ & $52^{\circ} 45^{\prime} 72$ & $3^{\circ} 40^{\prime} 31$ & 5.1 \\
\hline 41 & 26 Feb & $1987-1$ & $52^{\circ} 48^{\prime} 54$ & $4^{\circ} 02^{\prime} 99$ & 4.8 \\
\hline 42 & $26 \mathrm{Feb}$ & $1987-1$ & $52^{\circ} 50^{\prime} 63$ & $4^{\circ} 21^{\prime} 11$ & 4.9 \\
\hline $45-48$ & $16 \mathrm{Mar}$ & $1987-2$ & $52^{\circ} 57^{\prime} 75$ & $4^{\circ} 40^{\prime} 16$ & 4.7 \\
\hline 54 & $19 \mathrm{Mar}$ & $1987-2$ & $52^{\circ} 56^{\prime} 61$ & $4^{\circ} 41^{\prime} 00$ & 4.6 \\
\hline $60-63$ & 23 Mar & $1987-3$ & $52^{\circ} 51^{\prime} 56$ & $3^{\circ} 32^{\prime} 19$ & 4.5 \\
\hline $70-71$ & $24 \mathrm{Mar}$ & $1987-3$ & $53^{\circ} 18^{\prime} 68$ & $5^{\circ} 02^{\prime} 84$ & 4.5 \\
\hline $73-74$ & $24 \mathrm{Mar}$ & $1987-3$ & $53^{\circ} 28^{\prime} 73$ & $5^{\circ} 24: 55$ & 4.4 \\
\hline 83 & $25 \mathrm{Mar}$ & $1987-3$ & $53^{\circ} 34^{\prime} 27$ & $6^{\circ} 28^{\prime} 38$ & 4.3 \\
\hline $104-105$ & 22 Feb & 1988-1 & $52^{\circ} 24^{\prime} 71$ & $3^{\circ} 26^{\prime} 68$ & 7.0 \\
\hline $119-120$ & $8 \mathrm{Mar}$ & $1988-2$ & $52^{\circ} 50^{\prime} 57$ & $3^{\circ} 22^{\prime} 54$ & 6.1 \\
\hline 123 & $9 \mathrm{Mar}$ & $1988-2$ & $52^{\circ} 03^{\prime} 08$ & $3^{\circ} 07^{\prime} 69$ & 6.4 \\
\hline $132-134$ & $10 \mathrm{Mar}$ & $1988-2$ & $52^{\circ} 52^{\prime} 85$ & $4^{\circ} 06^{\prime} 06$ & 5.9 \\
\hline 135 & $10 \mathrm{Mar}$ & $1988-2$ & $52^{\circ} 53^{\prime} 41$ & $4^{\circ} 23^{\prime} 46$ & 6.0 \\
\hline 145 & $22 \mathrm{Mar}$ & $1988-3$ & $53^{\circ} 10^{\prime} 36$ & $3^{\circ} 42^{\prime} 49$ & 6.8 \\
\hline 146 & $22 \mathrm{Mar}$ & $1988-3$ & $53^{\circ} 08^{\prime} 19$ & $3^{\circ} 49^{\prime} 12$ & 6.4 \\
\hline 157 & $28 \mathrm{Mar}$ & $1988-4$ & $53^{\circ} 11^{\prime} 09$ & $3^{\circ} 43^{\prime} 28$ & 7.4 \\
\hline 218 & $25 \mathrm{Jan}$ & $1989-1$ & $52^{\circ} 45^{\prime} 61$ & $3^{\circ} 30^{\prime} 77$ & 7.8 \\
\hline 220 & 21 Feb & $1989-2$ & $52^{\circ} 42^{\prime} 66$ & $3^{\circ} 27^{\prime} 41$ & 7.8 \\
\hline 223 & $7 \mathrm{Mar}$ & $1989-3$ & $52^{\circ} 07^{\prime} 56$ & $3^{\circ} 56^{\prime} 66$ & 7.6 \\
\hline $225-227$ & $7 \mathrm{Mar}$ & $1989-3$ & $52^{\circ} 39^{\prime} 90$ & $3^{\circ} 27^{\prime} 42$ & 7.4 \\
\hline $233-235$ & $6 \mathrm{Mar}$ & $1989-4$ & $52^{\circ} 52^{\prime} 97$ & $4^{\circ} 29^{\prime} 75$ & 7.1 \\
\hline
\end{tabular}

When possible, fish larvae were sorted on board and preserved in $96 \%$ ethanol, otherwise the total catch was preserved in $96 \%$ ethanol, which was replaced within $24 \mathrm{~h}$, and sorted in the laboratory within $2 \mathrm{wk}$. In 1987 some catches were preserved in a buffered $4 \%$ formaldehyde solution, but this damaged many of the otoliths within $24 \mathrm{~h}$.

Inshore, migrating late larvae and early juveniles were sampled daily in the Marsdiep, a main inlet of the Dutch Wadden Sea. A bongo-type net was used (opening $1 \mathrm{~m}^{2}$, mesh size $1 \mathrm{~mm}$ ), which was moored at a jetty in the Marsdiep about $15 \mathrm{~m}$ offshore and emptied every $24 \mathrm{~h}$, when permitted by climatological circumstances. In 1987 a random sample of 10 larvae $\mathrm{d}^{-1}$ was taken. In 1988 and 1989 a random sample of 5 larvae $\mathrm{d}^{-1}$ was taken. If less larvae were caught, they were all used.

Sagittal otoliths were removed, air-dried, and mounted in clear nail polish. Small otoliths were mounted sulcus-side down, larger otoliths were mounted sulcus-side up. After preliminary light microscopical examination, otoliths in which increments were not clearly visible were ground and polished with 800 grain sandpaper and 1200 grain alumina polishing powder, respectively. Otoliths were photographed on high-contrast black and white film using transmitted light at magnifications varying from 250 to $2000 \times$. Negatives were projected with a slide projector For each otolith, 3 increment counts were made. If the lowest and highest count differed by more then $10 \%$ of the average, or by 3 (absolutely) the otolith was rejected. All counts were made without knowledge of larval size or capture date.

Otoliths were not always completely circular, and a mean diameter was calculated from the minimum and maximum diameter. The nucleus was often located asymmetrically, and so all measured distances were standardized to the mean otolith radius by calculating a standardized measurement: $M_{s}=M_{d} \times\left(R_{t} / R_{d}\right)$ where $M_{d}=$ measured distance, $R_{t}=$ reading transect and $R_{d}$ = standard radius, calculated as (minimum diameter + maximum diameter)/4

A positive relationship was observed between otolith diameter and otolith radius of the first increment, i.e. the distance from the first increment to the otolith nucleus increased with the diameter of the otolith. This may have been an optical artifact caused by a reduced transparency of larger otoliths, which may have caused the early increments to be missed in the increment counts. Furthermore, a significant positive linear relationship was found between increment width and increment radius. Offshore larvae were in general younger and smaller than inshore larvae and consequently otoliths of offshore larvae were generally smaller than those of inshore larvae. A direct comparison of increment widths would consequently have generated apparently wider increments in the larger otoliths of offshore larvae and have lead to incorrect conclusions.

To correct this, the average increment width of Increments 1 to 10 was regressed on the radius of Increment 1 , the average increment width of Increments 11 to 20 on the radius of Increment 10 , etc. A logarithmic transformation of both variables was applied to make variances independent of the mean. After calculating the linear regression lines, the residuals were taken as an index of otolith growth. When otolith growth is above average, otolith growth indices will be positive, and when growth is below average, indices will be negative.

To demonstrate growth-dependent mortality it would have been ideal to follow the same cohort of larvae, and to sample it at different stages, but this would have been very difficult as well as costly. Instead, for this study I calculated the day on which each individual larva had started depositing visible increments by subtracting the number of increments from the day of capture. Otolith increment-deposition was demonstrated to be daily in larvál and juvenile plaice (Karakiri \& Westernhagen 1989). The seasons 
were divided into periods of $10 \mathrm{~d}$, starting with 1 January, so periods in November-December of the preceding years were signed negative. Larvae were divided into 'cohorts' which had started increment formation in the same period. Larvae from the same $10 \mathrm{~d}$ period of first increment formation belonged to the same 'cohort'.

Average otolith growth indices were calculated for offshore and inshore larvae, for all periods in which at least 10 larvae were available from both locations. Differences between offshore and inshore larvae were tested applying a 2-factor analysis of variance with location and period of increment formation as factors.

The intensity of selection can be estimated by comparing the relative frequency distributions of otolith growth indices from offshore and inshore larvae, analogous to the method used for scale circuli by Healey (1982). Otolith growth indices were divided into 10 classes and frequency distributions were calculated separately for inshore and offshore larvae. For each growth-class the ratio was calculated between the relative frequencies of the offshore and inshore larvae: $R_{s}=$

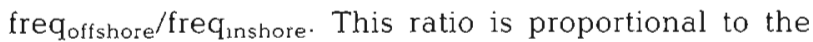
relative survival of each growth-class, and henceforth called the 'survival ratio'. Not enough data were available to calculate separate frequency distributions and survival ratios for each cohort, so all cohorts within each yr were pooled.
Results. Sufficient numbers of larvae from offshore and inshore locations were sampled from ca 20 February to 1 May 1987, ca 20 February to 20 April 1988 and ca 20 January to 20 April 1989. In 1987 growth of Increments 1 to 40 were compared, in 1988 Increments 1 to 30 , and in 1989 Increments 1 to 20, due to differences in larval age.

Otolith growth indices were plotted against the period in which they were formed for each year (Figs. 2, 3 \& 4). In 1987 otolith growth of Increments 1 to 40 was faster in the inshore larvae than in the offshore larvae. In 1988 growth of Increments 1 to 20 was faster in the inshore larvae, but there is no difference for Increments 21 to 30 . In 1989 only growth of Increments 1 to 10 was significantly faster in the inshore larvae. The observed difference in Increments 11 to 20 had the expected sign, but was not significant at $\alpha=0.05$ ( $\mathrm{p}=$ 0.074 ).

Relative frequencies of otolith growth indices and the resulting survival ratios are presented in Table 2 . The smallest growth-classes were rarely observed in inshore larvae, while the largest growth-classes were more abundant in the inshore larvae. In all cases the survival ratios increased with increasing growth-class, demonstrating a progressively higher chance of survival for faster-growing larvae.

Discussion. Growth-dependent mortality is demonstrated to have operated in each of the 3 investigated

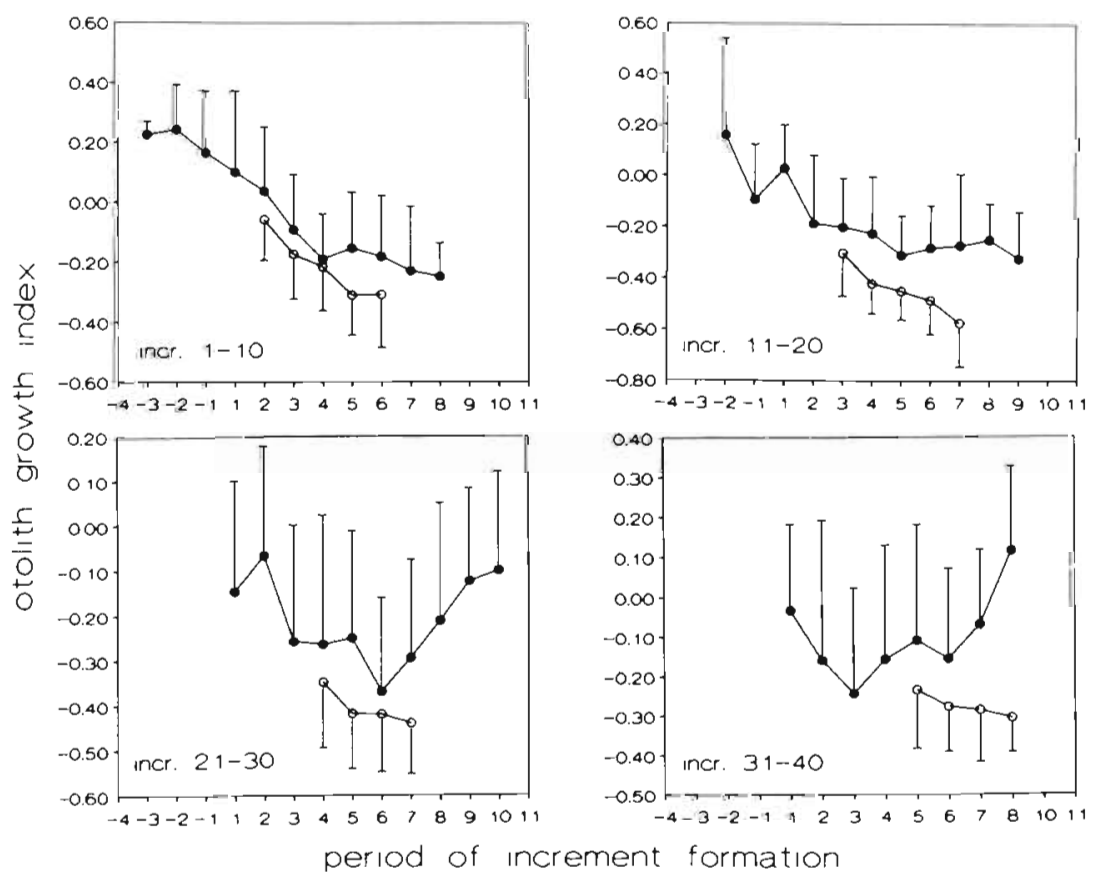

Fig. 2. Otolith growth indices per 10 increments for each period of formation for $1987 .(-\bullet)$ Inshore, (-०) offshore 
1988
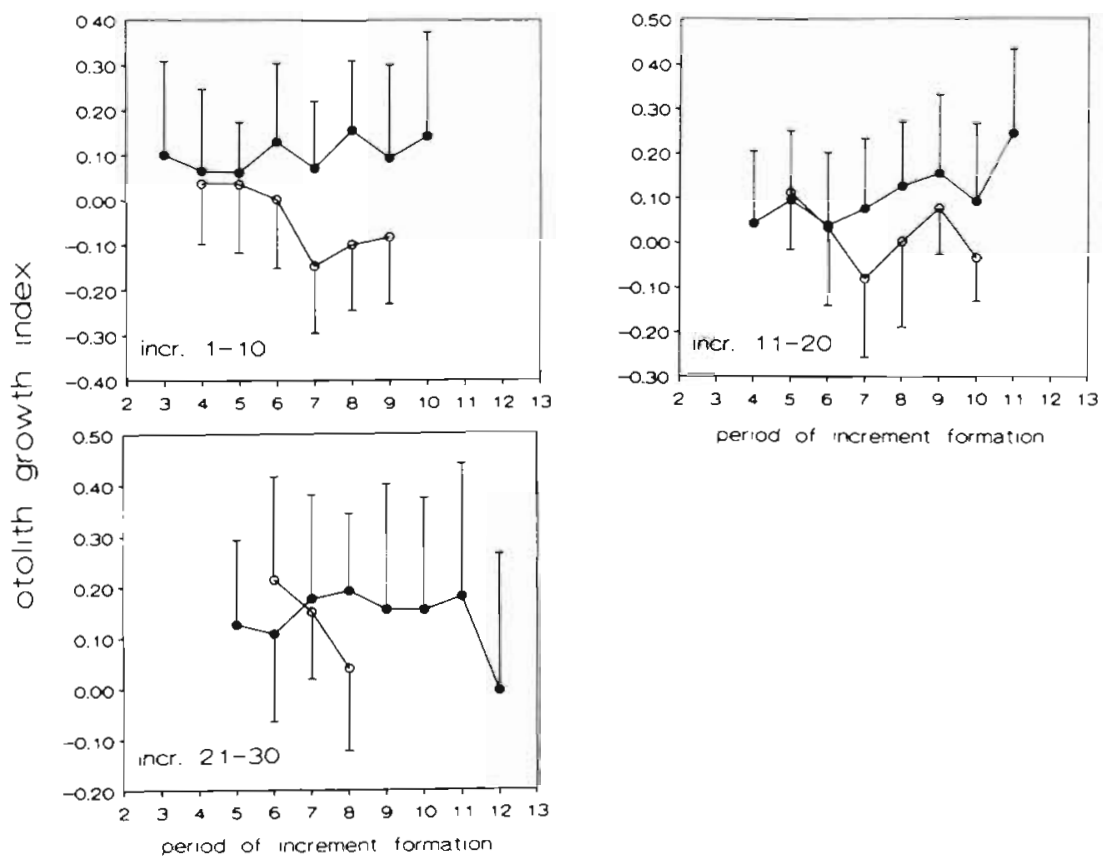

Fig. 3. Otolith growth indices per 10 increments for each period of formation for 1988. ( $\bullet-)$ Inshore, $(-0)$ offshore

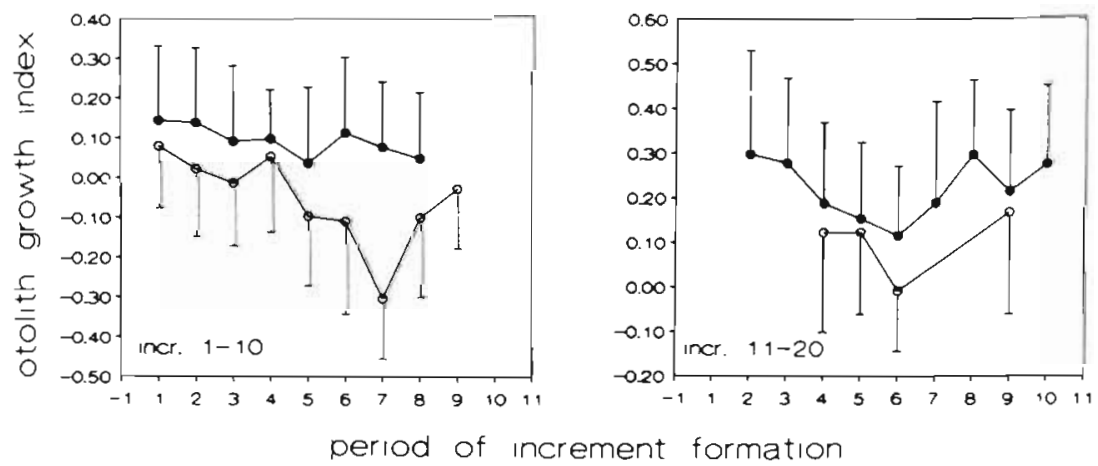

Fig. 4. Otolith growth indices per 10 increments for each period of formation for 1989. (-) Inshore, (- -) offshore

years. Otolith growth indices were almost consistently higher in larvae caught inshore than in larvae sampled at open sea. As each cohort was only sampled twice, not much can be said about the timing of this mortality, but it seems certain that metamorphosing and immigrating larvae have been subject to growth-clependent selection. In 1987 most of the offshore larvae were sampled close to the inlets of the Wadden Sea. These larvae were only 7 to $15 \mathrm{~d}$ younger than the larvae sampled in the Marsdiep, and even during this short period a rather strong growth-dependent mortality had taken place. In 1988 and 1989 the offshore larvae were sampled at open sea, and at a much younger age than the inshore larvae, and no more precise conclusions can be inferred about the timing of mortality related to the age or stage of the larvae.

Otolith growth was shown to be correlated between subsequent life stages (Hovenkamp 1989), possibly by means of a spurious correlation with temperature. This may explain the observation that even in the 1987 
Table 2. Pleuronectes platessa. Relative frequencies of growth-classes and the resulting survival ratios (SR) of larval plaice sampled offshore (Off) and inshore (In) for 1987 to 1989

\begin{tabular}{|c|c|c|c|c|c|c|c|c|c|c|c|c|}
\hline \multirow{3}{*}{$\begin{array}{l}\text { Growth } \\
\text { class }\end{array}$} & \multicolumn{3}{|c|}{ Increments $1-10$} & \multicolumn{3}{|c|}{ Increments $11-20$} & \multicolumn{3}{|c|}{ Increments $21-30$} & \multicolumn{3}{|c|}{ Increments $31-40$} \\
\hline & \multicolumn{2}{|c|}{ Rel. freq. } & \multirow[t]{2}{*}{$\mathrm{SR}$} & \multicolumn{2}{|c|}{ Rel. freq. } & \multirow[t]{2}{*}{ SR } & \multicolumn{2}{|c|}{ Rel. freq. } & \multirow[t]{2}{*}{$\mathrm{SR}$} & \multicolumn{2}{|c|}{ Rel. freq. } & \multirow[t]{2}{*}{$\mathrm{SR}$} \\
\hline & Off & In & & Off & In & & Off & In & & Off & In & \\
\hline & & & & & & 1987 & & & & & & \\
\hline 1 & 0.00 & 0.00 & - & 0.63 & 1.15 & 1.825 & 0.00 & 1.20 & $\infty$ & 0.00 & 0.00 & - \\
\hline 2 & 1.25 & 1.14 & 0.912 & 15.82 & 5.17 & 0.327 & 7.64 & 7.78 & 1.018 & 0.00 & 0.68 & $\infty$ \\
\hline 3 & 13.75 & 3.98 & 0.289 & 46.20 & 21.84 & 0.473 & 45.83 & 23.95 & 0.523 & 15.15 & 9.52 & 0.628 \\
\hline 4 & 37.50 & 28.98 & 0.773 & 31.01 & 37.36 & 1.205 & 40.28 & 29.34 & 0.728 & 60.61 & 31.29 & 0.516 \\
\hline 5 & 36.25 & 37.50 & 1.034 & 5.06 & 23.56 & 4.656 & 6.25 & 19.16 & 3.066 & 20.20 & 30.61 & 1.515 \\
\hline 6 & 10.00 & 19.32 & 1.932 & 1.27 & 9.77 & 7.693 & 0.00 & 16.17 & $\infty$ & 4.04 & 19.05 & 4.715 \\
\hline 7 & 1.25 & 8.52 & 6.816 & 0.00 & 1.15 & $\infty$ & 0.00 & 2.40 & $\infty$ & 0.00 & 8.84 & $\infty$ \\
\hline 8 & 0.00 & 0.57 & $\infty$ & 0.00 & 0.00 & - & 0.00 & 0.00 & - & 0.00 & 0.00 & - \\
\hline 9 & 0.00 & 0.00 & - & 0.00 & 0.00 & - & 0.00 & 0.00 & - & 0.00 & 0.00 & - \\
\hline 10 & 0.00 & 0.00 & - & 0.00 & 0.00 & - & 0.00 & 0.00 & - & 0.00 & 0.00 & - \\
\hline \multirow[t]{2}{*}{$\mathrm{n}=$} & 160 & 176 & & 158 & 174 & & 144 & 168 & & 99 & 149 & \\
\hline & & & & & & 1988 & & & & & & \\
\hline 1 & 0.00 & 0.00 & - & 0.00 & 0.00 & - & 0.00 & 0.00 & - & & & \\
\hline 2 & 0.00 & 0.00 & - & 0.00 & 0.00 & - & 0.00 & 0.33 & $\infty$ & & & \\
\hline 3 & 1.53 & 0.30 & 0.196 & 1.44 & 0.30 & 0.208 & 3.51 & 0.66 & 0.188 & & & \\
\hline 4 & 9.48 & 3.29 & 0.347 & 5.74 & 3.89 & 0.678 & 3.51 & 5.92 & 1.687 & & & \\
\hline 5 & 42.51 & 29.04 & 0.683 & 33.97 & 22.16 & 0.652 & 17.54 & 14.80 & 0.844 & & & \\
\hline 6 & 34.86 & 42.81 & 1.228 & 41.15 & 44.61 & 1.084 & 47.37 & 34.87 & 0.736 & & & \\
\hline 7 & 10.40 & 16.77 & 1.612 & 13.40 & 23.05 & 1.720 & 19.30 & 30.92 & 1.602 & & & \\
\hline 8 & 0.92 & 6.89 & 7.489 & 4.31 & 5.09 & 1.181 & 7.02 & 11.84 & 1.687 & & & \\
\hline 9 & 0.31 & 0.90 & 2.903 & 0.00 & 0.90 & $\infty$ & 1.75 & 0.66 & 0.377 & & & \\
\hline 10 & 0.00 & 0.00 & - & 0.00 & 0.00 & - & 0.00 & 0.00 & - & & & \\
\hline \multirow[t]{2}{*}{$\mathrm{n}=$} & 315 & 130 & & 197 & 130 & & 47 & 69 & & & & \\
\hline & & & & & & 1989 & & & & & & \\
\hline 1 & 0.00 & 0.00 & - & 0.00 & 0.00 & - & & & & & & \\
\hline 2 & 0.00 & 0.00 & - & 1.12 & 0.00 & 0.000 & & & & & & \\
\hline 3 & 2.16 & 0.00 & 0.000 & 0.00 & 0.00 & - & & & & & & \\
\hline 4 & 20.69 & 3.17 & 0.153 & 5.62 & 1.77 & 0.315 & & & & & & \\
\hline 5 & 39.66 & 24.30 & 0.613 & 15.73 & 10.25 & 0.652 & & & & & & \\
\hline 6 & 28.43 & 42.61 & 1.499 & 44.94 & 32.51 & 0.723 & & & & & & \\
\hline 7 & 7.33 & 24.30 & 3.315 & 23.60 & 37.46 & 1.587 & & & & & & \\
\hline 8 & 1.29 & 4.23 & 3.279 & 7.87 & 15.55 & 1.976 & & & & & & \\
\hline 9 & 0.43 & 1.41 & 3.279 & 1.12 & 1.77 & 1.580 & & & & & & \\
\hline 10 & 0.00 & 0.00 & - & 0.00 & 0.71 & $\infty$ & & & & & & \\
\hline $\mathrm{n}=$ & 231 & 283 & & 78 & 182 & & & & & & & \\
\hline
\end{tabular}

larvae, with already 40 or more increments, there was a selection for larvae with slow otolith growth during their early life.

Survival ratios given in Table 2 must be regarded as only rough estimates. Otolith growth indices differ substantially between periods, especially in 1987, and pooling the data may have introduced some bias. Cautiously, it may be inferred though that the slowest growing larvae had roughly a 3 times lower chance of survival (from Stage 2 to $4 \mathrm{~A}$ to almost complete metamorphosis) than the fastest growing larvae.

An important assumption in this study is that the larvae for which otolith growth is compared are indeed from the same cohort. Unfortunately this is impossible to prove. With the applied method of back-calculating it is certain at least that the compared increments were formed during the same period, which is confirmed by the similarities in the patterns of growth through the season. Moreover, the time of spawning in plaice is related to the location of spawning, which improves the chance that larvae hatched at the same time originated from the same location.

Regarding the concept of size-selective mortality, a distinction has to be made between the terms 'sizeselective' and 'growth-dependent'. At a constant rate of mortality, the individual chance of surviving a stage will be dependent on the stage duration and therefore on growth rate (growth-dependent mortality), and there will be a positive selection for the fast-growing individuals. This effect can be intensified by size- 
selective mortality, by which a differential rate of mortality for different sizes is meant, e.g. because of reduced escape abilities of smaller larvae. Although the ultimate effect of both processes is identical, they operate in different ways, and a conceptual distinction is necessary for a better comprehension of the relation between growth and mortality.

The most important factor to cause size-selective mortality will be predation. Herring Clupea harengus L. and sprat Sprattus sprattus L. are known to feed on plaice eggs (Pommeranz 1981, Daan et al. 1985) which are easily identified in stomachs. However, small flatfish larvae are much more difficult to trace, and other important predators on the pelagic stages have not yet been identified. New immunochemical techniques, which are presently being developed, might provide better possibilities to identify predators on fish larvae (Theilacker et al. 1986). In the coastal zone however, several important predators have been identified, i.e. the coelenterates Pleurobrachia pileus and Aurelia aurita, and the brown shrimp Crangon crangon (Veer 1985, Veer \& Bergman 1987). Pleurobrachia and Aurelia are strictly pelagic and may prey on larval plaice, while shrimps are known to predate on early juvenile larvae, which are already demersal. Predation by shrimps is highly size-dependent, and supposed to be the single most important factor causing mortality of newly settled 0-group plaice (Veer \& Bergman 1987). Metamorphosing plaice larvae ingested by $P$. pileus were regularly found in the inshore catches, but also with fin-bites which are characteristic for unsuccessful shrimp attacks (Veer \& Bergman 1987).

Bailey (1984) reported that predation rates of fish larvae were closely related to larval length and escape swimming speed, and that larval length itself was correlated to indices of escape ability for several species of fish larvae, including plaice. Especially during the earliest pelagic life stages the effect of size-selective mortality might be dramatic. A small increase in the mortality rate at this stage may cause a large absolute reduction in numbers, because of the large number of larvae still involved.

The question arises whether size-selective mortality is needed at all to explain the observed survival ratios. Hypothetical survival ratios were calculated and plotted for different mortality rate and time intervals (Fig. 5). It can be seen that for a survival ratio of 3 , a time interval of $\mathrm{ca} 10 \mathrm{~d}$ is needed at a mortality of $0.1 \mathrm{~d}^{-1}$. and of ca $20 \mathrm{~d}$ at a mortality rate of $0.06 \mathrm{~d}^{-1}$. Harding et al. (1978) reported daily mortality rates for plaice larvae Stages 3 and 4 ranging from 0.009 to $0.065 \mathrm{~d}^{-1}$. It was argued however in Hovenkamp (1991) that these values have probably been underestimated by a factor of 2 , resulting in actual mortality rates of ca 0.02 to $0.13 \mathrm{~d}^{-1}$. The difference between the mean ages of offshore and

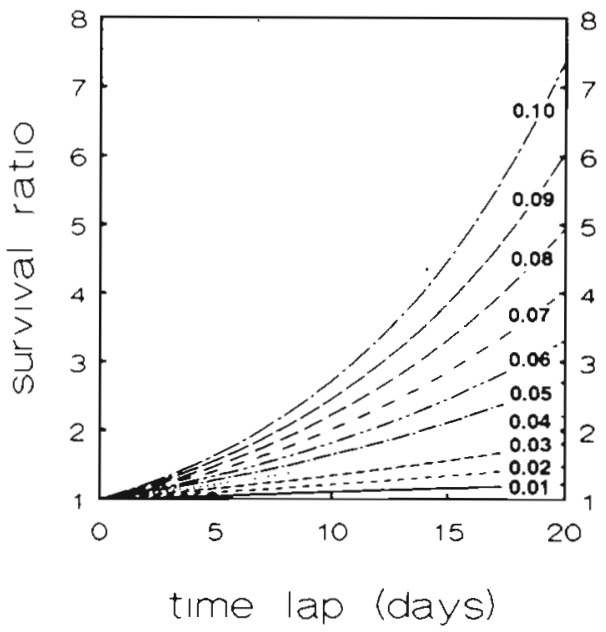

Fig. 5. Calculated survival ratios based on a daily mortality ranging from 0.01 to $0.1 \mathrm{~d}^{-1}$ and intervals from 0 to $20 \mathrm{~d}$

inshore larvae was $9 \mathrm{~d}$ in $1987,24 \mathrm{~d}$ in 1988 and $19 \mathrm{~d}$ in 1989. Given the large variability in larval growth rates of plaice no size-selective mortality is therefore needed to explain the observed survival ratios, although it may have occurred.

The observation that back-calculated lengths from otoliths from old fish are often smaller than actually observed at the time is known as Lee's phenomenon (Lee 1912, Ricker 1969). It has recently been argued (Campana 1990) that this phenomenon could be partially explained by different scaling relationships between fish length and otolith size, induced by differences in growth. Although such different scaling relationships were observed in larval plaice (Hovenkamp 1990), they were not used in calculating the differences in growth. However, it is clear that Lee's phenomenon will inevitably occur whenever there are differences in growth rate, unless there is a selection in favour of slow-growing individuals.

The methods used in this study may have practical implications for the study of size-selective mortality in the field. If a patch of larvae could be followed during its drift, and the actual rates of growth and mortality were known, a comparison of the distributions of the observed and calculated survival ratios would theoretically give information on the strength of the size-selectivity of mortality in the field.

\section{LITERATURE CITED}

Bailey, K. M. (1984). Comparison of laboratory rates of predation on five species of marine fish larvae by three planktonic invertebrates: effects of larval size on vulnerability. Mar Biol. 79: 303-309

Bailey, K. M., Batty, R. S. (1984). Laboratory study of predation 
by Aurelia aurita on larvae of cod, flounder, plaice and herring: development and vulnerability to capture. Mar Biol. 83: 287-291

Campana, S. E. (1990). How reliable are growth back-calculations based on otoliths? Can. J. Fish. Aquat. Sci. 47 2219-2227

Campana, S. E., Neilson, J. D. (1985). Microstructure of fish otoliths. Can. J. Zool. 42: 1014-1032

Daan, N., Rijnsdorp, A. D., Overbeke, G. R. van (1985). Predation by North Sea herring Clupea harengus on eggs of plaice Pleuronectes platessa and cod Gadus morhua. Trans. Am. Fish. Soc. 114: 499-506

Harding, D., Nichols, J. H., Tungate, D. S. (1978). The spawning of the plaice (Pleuronectes platessa) in the Southern North Sea and the English Channel. Rapp. P.-v. Réun. Cons. int. Explor Mer 164: 102-113

Healey, M. C. (1982). Timing and relative intensity of sizeselective mortality of juvenile chum salmon (Oncorhynchus keta) during early sea life. Can. J. Fish. Aquat. Sci. 39: 952-957

Houde, E. D. (1986). Potential for growth, duration of early life stages and regulation of recruitment in marine fish. Comm. Meet. int. Coun. Explor. Sea C.M.-ICES/L: 28

Houde, E. D. (1989). Subtleties and episodes in the early life of fish. J. Fish. Biol. 35 (Suppl. A): 29-38

Hovenkamp, F. (1989). Within-season variation in growth of larval plaice (Pleuronectes platessa L.). Rapp. P.-v. Réun. Cons. int. Explor Mer 191: 248-257

Hovenkamp, F. (1990). Growth differences in larval plaice (Pleuronectes platessa L.) in the Southern Bight of the North Sea as indicated by otolith increments and RNA/ DNA ratios. Mar. Ecol. Prog. Ser. 58: 205-215

Hovenkamp, F. (1991). Growth, otolith growth and RNA/ DNA ratios of larval plaice (Pleuronectes platessa L.) in the North Sea 1987 to 1989. Mar Ecol. Prog. Ser. 70 : $105-116$

Karakiri, M., Westernhagen, H. von (1989). Daily growth patterns in otoliths of larval and juvenile plaice Pleuronectes platessa L.: influence of temperature, salinity, and light

This note was submitted to the editor
Conditions. Rapp. P.-v. Réun. Cons. int. Explor. Mer 191 $376-382$

Lee, R. M. (1912). An investigation into the methods of growth determination in fishes. Cons. Perm. int. Explor. Mer, Publ. Circonstance 63

Pannella, G. (1971). Fish otoliths: daily growth layers and periodical patterns. Science 173: 1124-1127

Pommeranz, $T$ (1981). Observations on the predation of herring (Clupea harengus L.) and sprat (Sprattus sprattus L.) on fish eggs and larvae in the southern North Sea. Rapp. P.-v. Réun. Cons. int. Explor. Mer 164: 402-404

Ricker, W. E. (1969). Effects of size-selective mortality and sampling bias on estimates of growth, mortality, production and yield. J. Fish. Res. Bd Can. 26: 479-535

Theilacker, G. H., Kimball, A. S., Trimmer, J. S. (1986). Use of an ELISPOT immunoassy to detect euphasid predation on larval anchovy. Mar. Ecol. Prog. Ser. 30: 127-131

Veer, H. W. van der (1985). Impact of coelenterate predation on larval plaice Pleuronectes platessa and flounder Platichthys flesus in the western Wadden Sea. Mar. Ecol, Prog. Ser. 25: 229-238

Veer, H. W van der (1986). Immigration, settlement and density-dependent mortality of a larval and early postlarval 0-group plaice (Pleuronectes platessa) population in the western Wadden Sea. Mar Ecol. Prog. Ser. 29: 223-236

Veer, H. W van der, Bergman, M. J. N. (1987). Predation by crustaceans on a newly settled O-group plaice Pleuronectes platessa population in the western Wadden Sea. Mar. Ecol. Prog. Ser. 35: 203-215

Volk, E. C., Wissmar, R. C., Simenstad, C. A., Eggers, D. M. (1984). Relationship between otolith microstructure and the growth of juvenile chum salmon (Oncorhynchus keta) under different prey rations. Can. J. Fish. Aquat. Sci. 41. 126-133

Wilson, K. H., Larkin, P. H. (1982). Relationship between thickness of daily growth increments in sagittae and change in body weight of sockeye salmon (Oncorhynchus nerka) fry. Can. J. Fish. Aquat. Sci. 39: 1335-1339

Manuscript first received: March 26, 1991

Revised version accepted: February 24, 1992 